\title{
E-Government Kependudukan Indonesia: Pengembangan Instrumen dan Evaluasi Website Kependudukan Indonesia
}

\author{
E-Government of Indonesian Demographic: Development \\ Instrument and Evaluation of Indonesian Demographic Website
}

\author{
INNE LARASATI, YANI NURHADRYANI*
}

\begin{abstract}
Abstrak
Indonesia menduduki posisi ke-4 sebagai negara yang memiliki penduduk terbanyak di dunia. Oleh karena itu data statistik kependudukan sangatlah penting bagi pemerintah dan organisasi dalam merumuskan pembangunan dan bagi masyarakat dalam melakukan berbagai aktivitas. Selayaknya data statistik kependudukan mudah diakses, up-to-date dan disajikan dalam berbagai bentuk yang informatif misalnya melalui website. Dengan website masyarakat/organisasi dapat mengakses informasi dan melakukan transaksi data kependudukan seperti registrasi kelahiran, kematian, pernikahan/perceraian atau perpindahan penduduk. Seiring dengan penerapan e-government di Indonesia, paper ini mengevaluasi sejauh mana BPS sebagai lembaga penyedia data statistik termasuk statistik kependudukan memafaatkan ICT terutama website sebagai media pelayanan publik. Evaluasi dilakukan pada website milik BPS di tingkat pusat, provinsi dan kabupaten/kota dengan menggunakan instrumen kependudukan yang dikembangkan dan hasilnya dianalisis secara kuantitatif. Hasil evaluasi menunjukkan website hanya berfungsi sebagai penyedia informasi kependudukan yang bersifat statis, kurang informatif dan belum memiliki layanan online seperti transaksi data kependudukan sehingga masyarakat masih harus mendatangi kantor pemerintahan untuk mendapatkan layanan tersebut. Kondisi website BPS yang masih berada pada level web presence ini menunjukkan bahwa implementasi e-government Indonesia memerlukan penanganan yang serius seperti managemen database dan sistem yang lebih kompleks untuk mencapai level interaction dan transaction.
\end{abstract}

Kata kunci: e-government, indikator kependudukan, Indonesia, service online, web presence

\begin{abstract}
Indonesia is the 4th rank country with the biggest population in the world. Therefore demographic statistic is very important for government, organizations and citizens in variety activities. Demographic statistics should be easily accessible, up-to-date and presented in informative ways such as through website. Using website, user can access information and perform some online services such as demographics transactions (i.e registration of birth, death, marriage, etc). Along with the implementation of e-government in Indonesia, this paper evaluates to what extent does BPS (as the provider of demographic statistics) utilizes the Internet for providing public services. The evaluation conducted on BPS websites at the central, provincial and district using demographic indicators and quantitative analysis. The evaluation shows that BPS website is still at its early stage (web presence) with small portion of online services, so that the citizens still have to go to government offices to perform demographics transaction. This condition suggests that the implementation of e-government in Indonesia requires serious actions such as database management systems and more complex system in order to achieve the level of interaction and transaction.
\end{abstract}

Keywords: demographic indicator, e-government, Indonesia, online service, web presence 


\section{PENDAHULUAN}

Pada awal tahun 2012 Indonesia merupakan negara ke-4 dengan jumlah penduduk terbanyak di dunia setelah China, India, dan USA, yang tersebar di 33 provinsi (Geohive 2012). Analisis dan data kependudukan merupakan faktor penting dalam pengambilan kebijakan baik kebijakan pemerintahan maupun organisasi lainnya. Analisis kependudukan mencakup perolehan informasi dasar tentang distribusi penduduk, karakteristik, dan perubahan-perubahannya, penerangan sebab-sebab perubahan dari faktor dasar tersebut, dan penganalisaan segala konsekuensi yang mungkin terjadi di masa depan sebagai hasil dari perubahan-perubahan tersebut (Rusli 1996). Sistem informasi kependudukan adalah suatu sistem yang memberikan data statistik kependudukan di suatu negara (Kohler et al. 2002). Sistem informasi kependudukan biasanya terdiri atas dua komponen yaitu komponen yang berfungsi untuk melakukan pencatatan data kependudukan dan data vital statistik. Di masa yang akan datang diharapkan data dan analisis kependudukan Indonesia dapat diperoleh dengan mudah misalnya melalui website.

BPS adalah lembaga Non-Departemen yang bertanggung jawab langsung kepada presiden yang menangani statistik kependudukan di Indonesia yang berada di tingkat pusat, provinsi dan kabupaten/kota. Sesuai dengan Intruksi Presiden mengenai Kebijakan dan Strategi Nasional pengembangan e-Government (Inpres No 3/2003 dan Depkominfo 2009) dalam upaya pemanfaatan ICT (Information and Communications Technology) dalam menyelenggarakan pelayanan publik, BPS sudah mulai menggunakan website sebagai salah satu media pelayanannya. Implementasi e-government melalui website ini perlu dievaluasi untuk mengetahui sejauh mana kualitas informasi yang disampaikan.

Evaluasi terhadap penerapan e-government telah dilakukan oleh beberapa organisasi internasional maupun nasional seperti United Nations (United nations 2003, 2004, 2005, 2008, 2010) dan Depkominfo (2004). UN melakukan evaluasi secara periodik pada lebih dari 190 negara dengan menggunakan web measure index. Web measure index memiliki 4 level, yaitu web presence, interaction, transaction, dan participation (United Nations 2010; Lee 2007; Layne 2001). Semakin tinggi index e-government suatu negara maka semakin tinggi kualitas layanan yang diberikan. Webmeasure Index indonesia menempati urutan ke-106 pada tahun 2008 dan menurun menjadi peringkat ke-109 pada tahun 2010. UN melakukan evaluasi website tingkat nasional yaitu pemerintahan pusat.

Pada tahun 2010, evaluasi website di tingkat provinsi, kabupaten dan kota di Indonesia sebanyak 429 website dilakukan oleh Nurhadryani (Nurhadryani 2010) yang menyatakan bahwa Indonesia masih berada dalam tahap awal yaitu cataloging (Web Present) dengan online service yang sangat terbatas. Kemudian pada tahun 2011, Nurhadryani dan Kriyar membandingkan penilaian website provinsi pemerintahan Indonesia dan Kamboja menggunakan web measure index. Hasilnya menunjukkan bahwa kedua negara tersebut masih pada tahap cataloging, dan website Indonesia masih lebih baik daripada website pemerintahan Kamboja (Kriyar 2011). Pada tahun 2012 Ichsani melakukan evaluasi usability dan accessibility website provinsi di Indonesia (Ichsani 2012).

Evaluasi e-government termasuk evaluasi website pemerintahan perlu dilakukan terus menerus guna mengetahui sejauh mana pemerintahan tersebut menerapkan ICT sebagai alat untuk menyajikan layanan publik. Evaluasi website pemerintahan Indonesia dilakukan di tingkat nasional, provinsi dan lokal, namun belum banyaknya evaluasi pada suatu sektor tertentu atau departemen tertentu seperti pendidikan, keuangan, pertanian, kehutanan dll. Mengingat pentingnya data kependudukan maka penelitian ini bertujuan untuk mengetahui sejauh mana BPS memanfaatkan website sebagai media layanan statistik kependudukan.

Penelitian dilakukan dengan cara mengembangkan instrumen kependudukan kemudian dengan menggunakan instrumen tersebut dilakukan evaluasi pada website BPS yang mencakup evaluasi layanan/service apa saja yang disajikan dalam website BPS Indonesia. Evaluasi yang dimaksud meliputi: apakah website memuat informasi kependudukan dengan 
lengkap dan informatif? Apakah website telah mampu mencatat data vital penduduk berupa pertumbuhan pendudukan yang mencakup pencatatan kelahiran, kematian, pernikahan/ perceraian atau perpindahan penduduk? Apakah website sudah menyediakan layanan online sehingga masyarakat tidak harus datang ke kantor pemerintahan untuk mendapatkan layanan seperti registrasi kelahiran, kematian, pernikahan atau perpindahan? Apakah website sudah menjadi komunikasi antara BPS dengan pemerintah, organisasi dan masyarakat lainnya? Dengan menggunakan web measure index, evaluasi dilakukan untuk mengetahui tahap pengembangan website BPS Indonesia.

\section{METODE}

Penelitian dimulai dengan mengembangkan instrumen kependudukan sebagai alat untuk mengevaluasi website BPS. Kemudian dengan instrumen yang dikembangkan dilakukan evaluasi website kependudukan BPS Indonesia yang kemudian hasilnya dianalisis.

\section{Pengembangan Instrumen Kependudukan}

Instrumen kependudukan terdiri atas variabel-variabel berupa layanan kependudukan yang harus terdapat dalam websites BPS. Karena belum adanya instrumen kependudukan yang standar maka variabel disusun secara subjektif dari konten yang terdapat pada website statistik Kanada (www.statcan.gc.ga) yang merupakan website kependudukan terlengkap. Setiap variabel dikelompokkan ke dalam sejumlah indikator. Instrumen lainnya yang digunakan yaitu terdiri atas variabel-variabel yang terdapat pada web measure index yang digunakan oleh Nurhadryani (2010) dan Kriyar (2011).

\section{Evaluasi Website Kependudukan BPS Indonesia}

Evaluasi dilakukan pada website BPS di tingkat pusat, provinsi dan kabupaten/kota. Sebanyak 6 provinsi yaitu Aceh, Jawa Barat, Bali, Kalimantan Barat, Maluku, dan Papua, dipilih agar dapat mewakili Indonesia bagian barat, tengah, dan timur. Ke-6 provinsi tersebut memilki 110 kabupaten/kota sehingga total website yang dipilih sebanyak 117. Evaluasi awal dilakukan dengan memeriksa apakah website dapat diakses atau tidak. Hasil evaluasi awal menunjukkan bahwa hanya 62 dari 117 website BPS yang dapat diakses. Hampir 50\% BPS di tingkat kabupaten/kota memiliki alamat domain namun tidak dapat diakses (Tabel 1). Selanjutnya evaluasi hanya dilakukan terhadap 62 website tersebut ditambah satu website BPS pusat. Nama dan alamat website yang dievaluasi dapat dilihat pada Larasati 2012.

Evaluasi dilakukan setiap hari Sabtu, Minggu, dan Senin selama empat minggu pada tanggal 3-5, 10-12, 17-19, dan 24-26 Februari 2012. Angka-angka biner (1 dan 0) digunakan untuk menunjukkan apakah sebuah website menyediakan variabel-variabel yang dievaluasi berupa layanan kependudukan (1) atau tidak (0).

\section{Analisis Hasil Evaluasi Website Kependudukan}

Analisis dilakukan secara deskriptif melalui penyajian data dalam bentuk tabel yang berisi persentasi ketersedian suatu variabel kependudukan pada website di tingkat pusat, provinsi dan daerah (kabupaten/kota).

\section{HASIL DAN PEMBAHASAN}

\section{Instrumen Kependudukan Website BPS Indonesia}

Instrumen kependudukan yang dihasilkan terdiri atas 39 variabel yang dikelompokkan ke dalam 10 indikator (Tabel 2, kolom indikator). Indikator situs statistik kependudukan, pengunaan bahasa, berita dan informasi terbaru, alamat kontak lembaga statistik merupakan 
Tabel 1 Jumlah website BPS yang dapat diakses pada 26 Februari 2012 provinsi Aceh, Jawa Barat, Bali, Kalimantan Barat, Maluku, dan Papua

\begin{tabular}{lccc}
\hline \multirow{2}{*}{ Tingkat wilayah pemerintahan } & \multirow{2}{*}{ Jumlah Wilayah } & $\begin{array}{c}\text { Jumlah website yang dapat } \\
\text { Diakses }\end{array}$ & \multirow{2}{*}{$\%$} \\
\hline Pusat & 1 & 1 & 100 \\
Provinsi & 6 & 6 & 100 \\
Kabupaten & 87 & 45 & 52 \\
Kota & 23 & 10 & 43 \\
\hline Total & 117 & 62 & 53 \\
\hline
\end{tabular}

indikator informasi pendukung kependudukan yang harus terdapat pada website. Indikator visualisasi data statistik kependudukan merupakan indikator cara penyampaian data kependudukan pada website. Indikator data kuantitas penduduk, data pertumbuhan penduduk, data kualitas penduduk, waktu pencatatan, dan publikasi data kependudukan merupakan indikator jenis-jenis data kependudukan yang harus disampaikan pada website.

Instrumen Web measure index yang diambil dari Nurhadryani (2010) dan Kriyar (2011) terdiri atas 4 level (web present, interaction, transaction dan participation) dengan 18 variabel (Tabel 3, kolom variabel). Level Web Presence adalah level paling dasar di mana website harus dapat diakses, menyediakan informasi berita kependudukan, dan di-update secara berkala. Pada level interaction, selain website menyediakan informasi, pengguna website juga dapat beinteraksi dengan cara memberi komentar pada informasi tersebut, mengirim e-mail atau berdiskusi melalui forum diskusi. Pada level transaction, website mulai menyediakan layanan secara online misalnya masyarakat dapat melakukan transaksi data kependudukan seperti registrasi kelahiran, kematian (birth and birth record), perpindahan penduduk (make new passport and renewal visa). Transaksi data tersebut dilakukan dengan cara mengunduh, mengisi dan menggugah formulir serta melakukan pembayaran online jika ada biaya yang harus dibayarkan. Pada level Participantions, masyarakat dapat berpartisipasi seperti memberikan suaranya melalui jajak pendapat atau survei lainnya. Dari webmeasure index Nurhadryani (2010) dan Kriyar (2011) terdapat dua variabel yang tidak digunakan pada penelitian ini, yaitu license and permit dan e-voting karena variabel tersebut kurang relevan dengan website kependudukan.

\section{Hasil Evaluasi Website BPS Menggunakan Intrumen Kependudukan}

Hasil evaluasi berupa presentasi dari indikator yang diteliti terdapat pada Tabel 2. Indikator 1: Situs Statistik Kependudukan. Hampir seluruh situs BPS baik di tingkat provinsi maupun kabupaten/kota merupakan situs statistik kependudukan resmi milik pemerintah Indonesia. Sebanyak $74 \%$ website memiliki tautan ke website sektor lainnya, adanya link antara website BPS tingkat pusat, provinsi dan kabupaten. Hal ini menunjukkan mulai adanya integrasi antar BPS pusat, provinsi dan daerah (kabupaten) walaupun hanya berupa tautan website saja, belum pada tahapan integrasi database.

Indikator 2: Penggunaan Bahasa. Situs BPS yang sudah menggunakan bahasa secara multi-lingual adalah situs BPS provinsi Bali dan 5 situs BPS tingkat kabupaten/kota, yaitu Kabupaten Singkil, Ketapang, Kayong Utara, Kubu Raya, dan Seram bagian Barat. Sebagian besar (94\%) website BPS belum menyajikan informasi dalam bahasa Inggris, beberapa website masih menggunakan Google Translate sebagai alat penerjemah. Hal ini menunjukkan bahwa informasi statistik kependudukan Indonesia belum dapat dinikmati oleh dunia Internasional.

Indikator 3: Berita dan Informasi Terbaru. Website menampilkan berita kependudukan yang baru, serta beberapa berita dapat diunduh. Hasil menunjukkan hampir semua website (98\%) tidak mencantumkan tanggal terakhir website di-update. Hanya satu website provinsi yang mencantumkan tanggal update. Pada penelitian ini, rentang waktu yang digunakan adalah 30 hari sejak pengecekan dilakukan. Berita akan dinyatakan baru jika berita yang disampaikan tidak lebih dari 30 hari sejak pengecekan dilakukan, misalnya pengecekan 
dilakukan tanggal 26 januari 2012, maka berita dianggap baru jika berita tersebut tidak lebih lama dari 26 Desember 2011.

Tabel 2 Persentase jumlah website BPS yang menyediakan variabel-variabel kependudukan di tingkat pusat, provinsi, dan kabupaten/kota (26 Februari 2012)

\begin{tabular}{|c|c|c|c|c|c|}
\hline No & Indikator (variabel-variabel) & $\begin{array}{c}\text { Pusat } \\
(1 \text { website })\end{array}$ & $\begin{array}{l}\text { Provinsi } \\
(6 \text { website })\end{array}$ & $\begin{array}{l}\text { Kab/Kota } \\
(55 \text { website })\end{array}$ & $\begin{array}{c}\text { Total } \\
(62 \text { website })\end{array}$ \\
\hline 1 & Indikator 1: Situs Statistik Kependudukan & 100 & 92 & 77 & 79 \\
\hline 1.a & Merupakan bagian dari situs pemerintahan & 100 & 100 & 82 & 84 \\
\hline 1.b & Memiliki tautan dengan situs pemerintahan lain & 100 & 83 & 72 & 74 \\
\hline 2 & Indikator 2: Penggunaan Bahasa & 100 & 9 & 4 & 6 \\
\hline 2.a & Menggunakan bahasa Inggris & 100 & 0 & 0 & 2 \\
\hline 2.b & Menggunakan Multi-lingual & 100 & 17 & 8 & 10 \\
\hline 3 & Indikator 3: Keterbaruan Berita dan Informasi & 75 & 75 & 30 & 35 \\
\hline 3.a & $\begin{array}{l}\text { Memiliki informasi tanggal terakhir situs di- } \\
\text { update }\end{array}$ & 0 & 17 & 0 & 2 \\
\hline 3.b & Memiliki berita kependudukan & 100 & 100 & 62 & 66 \\
\hline 3.c & Informasi dan berita merupakan yang terbaru & 100 & 100 & 27 & 36 \\
\hline 3.d & Informasi dan berita dapat diunduh & 100 & 83 & 29 & 36 \\
\hline 4 & Indikator 4: Alamat Kontak Lembaga Statistik & 100 & 100 & 62 & 67 \\
\hline 4.a & Memiliki alamat kantor & 100 & 100 & 67 & 71 \\
\hline 4.b & Memiliki alamat e-mail & 100 & 100 & 62 & 66 \\
\hline 4.c & Memiliki nomor telepon dan/atau $f a x$ & 100 & 100 & 58 & 63 \\
\hline \multirow[t]{2}{*}{5} & Indikator 5: Visualisasi Data Statistik & & & & \\
\hline & Kependudukan & 38 & 31 & 21 & 22 \\
\hline 5.a & Data kependudukan ditampilkan dalam website & 100 & 100 & 42 & 48 \\
\hline \multirow[t]{2}{*}{$5 . \mathrm{b}$} & Data yang ditampilkan dapat diatur secara & & & & \\
\hline & dinamis oleh pengunjung situs & 0 & 17 & 0 & 2 \\
\hline 5.c & Data dapat diunduh dalam format Excel & 100 & 0 & 0 & 2 \\
\hline 5.d & Data dapat diunduh dalam format PDF & 0 & 17 & 37 & 34 \\
\hline 5.e & Data visual menggunakan tabel & 100 & 100 & 58 & 63 \\
\hline 5.f & Data visual menggunakan grafik lingkaran & 0 & 17 & 11 & 11 \\
\hline $5 . \mathrm{g}$ & Data visual menggunakan grafik batang & 0 & 0 & 13 & 12 \\
\hline 5.h & Data visual menggunakan grafik garis & 0 & 0 & 3 & 3 \\
\hline 6 & Indikator 6: Data Kuantitas Penduduk & 60 & 50 & 36 & 38 \\
\hline 6.a & Jumlah penduduk berdasarkan jenis kelamin & 100 & 100 & 59 & 63 \\
\hline 6.b & Berdasarkan kelompok umur & 0 & 17 & 31 & 29 \\
\hline 6.c & Berdasarkan daerah tempat tinggal & 100 & 100 & 51 & 56 \\
\hline 6.d & Menetap dan berpindah tempat & 100 & 33 & 40 & 40 \\
\hline 6.e & Berdasarkan kelompok etnis & 0 & 0 & 0 & 0 \\
\hline 7 & Indikator 8: Data Pertumbuhan Penduduk & 33 & 11 & 4 & 5 \\
\hline 7.a & Jumlah penduduk berdasarkan kelahiran & 0 & 17 & 9 & 9 \\
\hline 7.b & Berdasarkan kematian & 100 & 17 & 9 & 11 \\
\hline 7.c & Berdasarkan penyebab kematian & 0 & 0 & 0 & 0 \\
\hline 7.e & Berdasarkan tingkat kematian bayi & 100 & 17 & 3 & 6 \\
\hline 7.f & Berdasarkan status perkawinan & 0 & 17 & 4 & 5 \\
\hline 7.g & Berdasarkan jumlah anak per keluarga & 0 & 0 & 0 & 0 \\
\hline 8 & Indikator 9: Data Kualitas Penduduk & 75 & 34 & 15 & 17 \\
\hline \multirow[t]{2}{*}{ 8.a } & Jumlah penduduk berdasarkan jenis tempat & & & & \\
\hline & tinggal & 100 & 17 & 3 & 6 \\
\hline 8.b & Berdasarkan pendapatan keluarga & 0 & 0 & 0 & 0 \\
\hline 8.c & Berdasarkan tingkat pendidikan & 100 & 67 & 22 & 28 \\
\hline $8 . \mathrm{d}$ & Berdasarkan pekerjaan & 100 & 50 & 33 & 36 \\
\hline 9 & Indikator 10: Waktu Pencatatan & 50 & 46 & 23 & 26 \\
\hline \multirow[t]{2}{*}{ 9.a } & Data penduduk tercatat sejak kemerdekaan & & & & \\
\hline & negara & 0 & 0 & 0 & 0 \\
\hline $9 . b$ & Tercatat setiap bulan & 0 & 0 & 0 & 0 \\
\hline 9.c & Tercatat setiap tahun & 100 & 83 & 46 & 50 \\
\hline 9.d & Berdasarkan sensus penduduk & 100 & 100 & 47 & 53 \\
\hline 10 & Indikator 11: Publikasi & 100 & 67 & 36 & 40 \\
\hline \multirow[t]{2}{*}{ 10.a } & $\begin{array}{l}\text { Data kependudukan dipublikasikan kepada } \\
\text { masyarakat }\end{array}$ & 100 & 67 & 36 & 40 \\
\hline & Rata-rata $(\%)$ & 62 & 45 & 26 & 29 \\
\hline
\end{tabular}


Indikator 4: Alamat Kontak Lembaga Statistik. Lebih dari $50 \%$ website BPS memiliki informasi kontak yang dapat dihubungi oleh pengunjung. Hal ini akan memudahkan pengunjung untuk berkomunikasi dengan kantor BPS melalui e-mail, telepon atau fax.

Indikator 5: Visualisasi Data Statistik Kependudukan. Visualisasi data statistik kependudukan yang digunakan masih berupa tabel tanpa analisis maupun informasi lain yang lebih detail. Pengunjung website tidak dapat mengatur informasi secara dinamis/sesuai kebutuhan misalnya memilih parameter yang diinginkan. Selain itu, data hanya dapat diunduh dalam format PDF. Di lain pihak data dalam format Excel kadang diperlukan untuk kepentingan lain seperti analisis data kependudukan atau ekspor data ke format lainnya.

Indikator 6: Data Kuantitas Pendudukan. Sebanyak 32\% website sudah mulai menampilkan informasi kependudukan berdasarkan jenis kelamin, kelompok umur dan daerah tempat tinggal. Namun belum ada website yang menampilkan informasi kependudukan berdasarkan kelompok etnis.

Indikator 7: Data Pertumbuhan Penduduk. Hanya beberapa website yang memiliki data pertumbuhan penduduk yaitu website provinsi Bali, Kabupaten Subang dan Kabupaten Indramayu. Data yang dimiliki adalah data jumlah penduduk berdasarkan kelahiran, kematian, tingkat kematian bayi, dan status perkawinan. Hasil ini tidak mencapai $10 \%$, padahal data pertumbuhan penduduk termasuk data yang penting untuk melihat perkembangan penduduk di suatu daerah. Perkembangan penduduk dapat direkam melalui sistem informasi kependudukan yang berfungsi mencatat data kependudukan dan data vital statistik. Pencatatan data kependudukan terdiri atas data kelahiran, kematian, pernikahan/perceraian dan perpindahn alamat. Keempat data tersebut terintegrasi dengan database vital statistik yang merupakan penyimpanan data kependudukan secara utuh.

Indikator 8: Data Kualitas Penduduk. Hasil menunjukkan bahwa website BPS tingkat kabupaten/kota masih belum memiliki data kualitas penduduk secara lengkap. Belum ada website pada tingkat provinsi maupun kabupaten/kota yang menampilkan informasi jumlah penduduk berdasarkan pendapatan keluarga sehingga pengguna tidak dapat mengetahui seberapa besar perubahan taraf hidup penduduk dari waktu ke waktu.

Indikator 9: Waktu Pencatatan. Waktu pencatatan yang ditampilkan di website sebagian besar hanya didasarkan pada waktu sensus penduduk yang dilakukan 10 tahun sekali. Hal ini membuat pergerakan jumlah penduduk setiap tahunnya sulit diamati. Jika setiap penduduk yang lahir dan meninggal atau berpindah tempat terekam dengan baik, informasi jumlah pertambahan penduduk setiap tahun bisa didapatkan.

Indikator 10: Publikasi. Indikator ini memberikan hasil 39\%. Hal ini menunjukkan bahwa masih sedikit situs BPS tingkat provinsi dan kabupaten/kota yang memberikan informasi di situs yang bersangkutan tentang publikasi buku statistik kependudukan.

Secara keseluruhan hasil menunjukkan website BPS Indonesia baru menyajikan 29\% dari 39 variabel kependudukan yang dievalusi, hal ini menunjukkan website BPS masih kurang mampu menyajikan informasi kependudukan secara informatif. Website BPS pusat merupakan website yang paling banyak memenuhi variabel tersebut, diikuti oleh website BPS provinsi dan website BPS kabupaten/kota.

\section{Hasil Evaluasi Website BPS menggunakan Web Measure Index}

Level 1: Web Presence. Lebih dari $50 \%$ website telah menyampaikan informasi mengenai "tab about us", contact information dan link to other official webpage. Namun, masih sedikit situs yang memiliki konten bahasa Inggris (10\%), maupun website yang diupdate secara berkala (10\%).

Level 2: Interaction. Belum ada website yang menyajikan formulir yang dapat diunduh oleh pengguna, seperti formulir registrasi atau update status penduduk. Untuk melakukan registrasi kelahiran, kematian, pernikahan, perceraian atau pindah tempat, masyarakat masih harus mendatangi kantor BPS untuk mendapatkan formulir yang diperlukan. Berita-berita pemerintahan sudah ditampilkan, namun masyarakat belum dapat memberikan komentar dan 
Tabel 3 Persentase jumlah website BPS yang menyediakan variabel-variabel Web Measure index di tingkat pusat, provinsi dan kabupaten/kota (26 Februari 2012)

\begin{tabular}{|c|c|c|c|c|c|}
\hline No & Variabel & $\begin{array}{c}\text { Pusat } \\
(1 \text { website })\end{array}$ & $\begin{array}{c}\text { Provinsi } \\
(6 \text { website })\end{array}$ & $\begin{array}{l}\mathrm{Kab} / \mathrm{Kota} \\
\text { (55 website) }\end{array}$ & $\begin{array}{c}\text { Total } \\
(62 \text { website })\end{array}$ \\
\hline 1 & Level: Web Presence & 100 & 76 & 51 & 55 \\
\hline 1.a & Web launching & 100 & 100 & 82 & 84 \\
\hline 1.b & Tab about us & 100 & 100 & 67 & 71 \\
\hline 1.c & Contact information & 100 & 100 & 71 & 74 \\
\hline 1.d & Link to others official webpage & 100 & 100 & 73 & 76 \\
\hline 1.e & Regular update & 100 & 50 & 4 & 10 \\
\hline 1.f & English language & 100 & 17 & 7 & 10 \\
\hline 1.g & General news and activities & 100 & 67 & 56 & 58 \\
\hline 2 & Level : Interaction & 20 & 27 & 16 & 17 \\
\hline 2.a & Downloadable forms & 0 & 0 & 0 & 0 \\
\hline 2.b & Publication & 100 & 100 & 79 & 81 \\
\hline 2.c & e-mail and respond & 0 & 0 & 0 & 0 \\
\hline 2.d & Post comment & 0 & 33 & 2 & 5 \\
\hline 2.e & Online forums & 0 & 0 & 0 & 0 \\
\hline 3 & Level : Transaction & 0 & 13 & 7 & 8 \\
\hline 3.a & Fill out and submit forms & 0 & 67 & 36 & 39 \\
\hline 3.b & Payment transaction & 0 & 0 & 0 & 0 \\
\hline 3.c & Make new passport & 0 & 0 & 0 & 0 \\
\hline 3.d & Renewal visa & 0 & 0 & 0 & 0 \\
\hline 3.e & Birth and death record & 0 & 0 & 0 & 0 \\
\hline 4 & Level : Participation & 0 & 16 & 35 & 32 \\
\hline \multirow[t]{2}{*}{ 4.a } & Survey & 0 & 16 & 35 & 32 \\
\hline & Rata-rata (\%) & 50 & 47 & 34 & 36 \\
\hline
\end{tabular}

hanya dapat mengambil informasi yang sudah ada. Komunikasi baru berjalan satu arah dari BPS ke pengguna, tanpa tanggapan dari pengguna. Pada lev el 1 lebih dari $70 \%$ website menampilkan e-mail yang berfungsi untuk komunikasi, namun e-mail yang dikirimkan masih belum mendapat respon (lebih dari 2 bulan). Hal ini menunjukkan bahwa e-mail belum dijadikan sebagai alat komunikasi dua arah. Belum ada website BPS baik di pusat, provinsi maupun kabupaten/kota yang menyediakan sarana interaksi berupa forum diskusi $(0 \%)$.

Level 3: Transaction. Persentase untuk trnasaction hanya sebesar 7\%. Hasil ini menunjukkan bahwa situs-situs BPS tingkat provinsi dan kabupaten/kota belum dapat menyediakan sistem pelayanan masyarakat yang bersifat online $(0 \%)$. Pelayanan yang diberikan masih bersifat offline sehingga masyarakat masih harus mengunjungi kantor BPS untuk mendapatkan pelayanan yang diinginkan secara langsung.

Level 4: Participation. Situs-situs BPS tingkat provinsi (16\%) dan kabupaten/kota (34\%) sudah mulai menyediakan polling sederhana. Contoh polling yang tersedia adalah seberapa baik pelayanan BPS di tahun sebelumnya dan bidang/konten apa yang harus diperbaiki. Sedangkan pada website pusat belum menyediakan poling/survey sama sekali $(0 \%)$. Hal ini mengindikasikan kurangnya pengambilan pendapat masyarakat mengenai suatu isu tertentu.

Hasil evaluasi terhadap 62 website BPS yang dapat diakses menunjukkan bahwa sekitar $55 \%$ website BPS menyajikan variabel-variabel web presence, hanya $17 \%$ website yang menyajikan fasilitas untuk berinteraksi antara website dan pengguna. Hanya $18 \%$ website yang menyediakan proses transaction seperti download dan submit formulir. Hanya $32 \%$ website yang menyajikan fungsi partisipasi masyarakat. Hasil ini akan semakin menurun jika mengikutsertakan semua website dari kabupaten/kota yang terpilih (117 website; 62 website dapat diakses, 55 website tidak sapat diakses).

Pada tahap transaction belum ada website yang menyajikan pelayanan secara online, sulitnya pencapaian pada level transaction ini karena perlu dibangun komunikasi data dan manajemen data yang kompleks. Online servicemerupakan suatu layanan yang seluruh prosesnya dilakukan secara online, mulai dari input data, pengiriman data (upload data), sampai proses layanan selesai. Pada service online, masyarakat tidak harus bertatap muka dengan penyedia layanan karena semua layanan dilakukan melalui website. Sebagai contoh, 
dalam pembuatan akta kelahiran: masyarakat dapat mengetahui persyaratan untuk membuat akta kelahiran dari website, melakukan registrasi secara online (input data identitas, upload data yang diperlukan), mendapatkan respons dari kantor BPS mengenai status proses pembuatan akta sampai akta kelahiran tersebut tercetak.

Meskipun masih memerlukan perbaikan, hasil menunjukkan bahwa website pusat sudah memenuhi $50 \%$ dari variabel web measure indeks diikuti website tingkat provinsi (47\%) dan kabupaten (34\%), secara keseluruhan rata-rata website BPS memenuhi $36 \%$ variabel webmeasure index.

\section{SIMPULAN}

Penelitian yang dilakukan menunjukkan bahwa dari sample yang diambil hanya $50 \%$ BPS Indonesia di tingkat kabupaten / kota yang mempunyai website yang bisa diakses. Namun, website tersebut baru menyajikan $29 \%$ dari 39 variabel kependudukan. Website hanya dapat berfungsi sebagai penyedia informasi kependudukan yang bersifat statis, belum berfungsi sebagai penyedia service online seperti registrasi kelahiran, kematian, pernikahan/perceraian atau perpindahan penduduk. Masyarakat masih harus mendatangi kantor untuk proses yang berhubungan dengan kependudukan. Website belum dijadikan sebagai alat komunikasi antara BPS dan pengunjung.

Website BPS berada pada tahap paling awal (web presence). Hasil penelitian ini sama dengan hasil penelitian yang dilakukan pada tahun 2010 (Nurhadryani 2010). Hal ini menunjukkan bahwa selama 2 tahun terakhir penerapan e-government melalui website di Indonesia belum memperlihatkan kemajuan yang signifikan.

Saat ini, website BPS dan website pemerintah Indonesia masih dalam tahap menampilkan informasi statis (web presence). Hal ini menunjukkan e-government Indonesia memerlukan penanganan yang serius untuk menyajikan pelayanan online yang memerlukan manajemen database dan sistem yang lebih kompleks untuk dapat mencapai level interaction dan transaction.

\section{DAFTAR PUSTAKA}

[BPS] Badan Pusat Statistik Kab Brebes. 2012. Kegiatan sensus di Indonesia [Internet]. [diunduh 2012 Agu 31]. Tersedia pada: http://brebeskab.bps.go.id/index.php?option=c om_content\&view $=$ article $\& i d=265 \% 3$ Akegiatan-sensus-di-indonesia- $\&$ catid $=38 \% 3$ Ase nsus\&Itemid $=19$.

[Depkominfo] Departemen Komunikasi dan Informatika. 2004. Kondisi situs web pemerintahan Indonesia [Internet]. [diunduh 2009 Nov 22]. Tersedia pada: http://blogs.depkominfo.go.id/artikel/2006/01/17/kondisi-situs-web-pemerintah-daerah.

[Depkominfo] Departemen Komunikasi dan Informatika. 2009. Draft mengenai pelaksanaan e-government di instansi Pemerintah Pusat dan Daerah [Internet]. [diunduh 2009 Nov 30]. Tersedia pada: http://pih.depkominfo.go.id /?cat=10\&paged $=4$.

Geohive. 2012. Population statistics [Internet]. [diunduh 2012 Apr 8]. Tersedia pada: http://www.geohive.com.

Ichsani Y. 2012. Pengembangan framework untuk mengukur usability dan acccesibility pada situs-situs web e-government provinsi di Indonesia [tesis]. Bogor (ID): Institut Pertanian Bogor.

Kohler I, Kaltchev J, Dimova M. 2002. Integrated information system for demographic statistics 'ESGRAON-TDS' in Bulgaria. Demogr Res 6:325-254.

Kriyar E. 2011. Assessment of e-government in Cambodia and Indonesia by web measure index [skripsi]. Bogor (ID): Institut Pertanian Bogor. 
Larasati I. 2012. Pengembangan parameter situs kependudukan dan evaluasi 61 situs kependudukan pada 6 provinsi di Indonesia [skripsi]. Bogor (ID): Institut Pertanian Bogor.

Layne K. Lee J. 2001. Developing fully functional e-government: a four stage model. Gov Inform $Q$ 18:122-136.

Lee J. 2007. Search for stage theory in e-government development. Di dalam: Griffin David, Trevorrow P and Halpin E, editor. Developments in e-Government, A Critical Analysis, Amsterdam (NL): IOS Press.

Nurhadryani Y. 2009. Memahami konsep e-governance serta hubungannya dengan egovernment dan e-demokrasi. Di dalam : Seminar Nasional Informatika; Yogyakarta (ID), 2009 Mei 23. Yogyakarta: UPN "Veteran” Yogyakarta. hlm F111-F117.

Nurhadryani Y. 2010. Assessing the role of the internet in the democratization of governance: a comparative analysis of the development of e-Government in Indonesia since 1998 [disertasi]. Sendai (JP): Tohoku University.

Rusli S. 1996. Pengantar Ilmu Kependudukan. Jakarta: Lembaga Penelitian, Pendidikan dan Penerangan Ekonomi dan Sosial.

United Nations. 2003. Global e-government survey 2003 [Internet]. [diunduh 2009 Des 11]. Tersedia pada: http://unpan1.un.org/intradoc/groups/public/documents/un/unpan01606 6.pdf .

United Nations. 2004. Global e-government readiness report 2004: Towards access for opportunities. New York (US): United Nations Publ.

United Nations. 2005. Global e-government readiness report 2005: From e-government to einclusion. New York (US): United Nations Publ.

United Nations. 2008. UN e-Government Survey 2008: From e-Government to Connected Governance. New York (US): United Nations Publ.

United Nations. 2010. Web measure model: stages of e-government evolution [Internet]. [diunduh pada 2012 Jun 18]. Tersedia pada: http://www2.unpan.org/egovkb/ egovernment_overview/webmeasure.htm. 